\title{
AN OUNCE OF DISCRETION FOR A POUND OF FLESH: A SUGGESTED REFORM FOR USURY LAWS
}

General usury laws are an ineffective and troublesome anachronism, a lingering product of the medieval "fair price" doctrine perpetuated by the deeply ingrained antipathy to the moneylender. ${ }^{1}$ In force in all but four states, ${ }^{2}$ these statutes prohibit parties from contracting for any loan with an interest rate in excess of specified maximums, ranging from six per cent to twelve per cent per annum. ${ }^{3}$ Penalties against the usurious lender range from forfeiture of the entire principal and interest to forfeiture of only that portion of the interest in excess of the statutory maximum. ${ }^{4}$ As a result of narrow judicial construction of the term "loan," only a limited number of debtorcreditor relationships remain within the scope of these laws. And because of similar restrictions imposed on the definition of the term "interest," not all charges made in loan transactions are subject to the test of usury.

Popularly supposed to be necessary primarily to protect the small consumer borrower, usury laws have been replaced for the most part in this field by consumer loan legislation. The narrow definitions of "loan" and "interest" made evasion of the statutes easy, and the small borrower was generally unaware of his rights and often lacked the means to enforce them. ${ }^{6}$ Moreover, the limitations imposed on interest rates by usury statutes were so unrealistic as to invite evasion; risks encountered on small consumer loans far exceeded maximum interest rates. ${ }^{7}$ Recognition of these shortcomings led to wide-

1. See, generally, Ryan, Usury AND Usury Laws 35-57 (1924). The continued vitality of the irrational attitudes which have perpetuated these statutes is demonstrated in two recent articles which approved the Arkansas Supreme Court's invalidation of the state's small loan law on constitutional grounds. Collins \& Ham, The Usury Laze of Arkansas: A Study in Evasion, \& ARK. L. REv. 399 (1954) ; Penick, The Impact of Usury Law on Banks in Arkansas, 8 id. at 420 . See Strickler v. State Auto Finance Co., 220 Ark. 565, 249 S.W.2d 307 (1952) ; Winston v. Personal Finance Co., 220 Ark. 580, 249 S.W.2d 315 (1952).

2. Maine, Massachusetts and New Hampshire have no statutes limiting the interest rates which may be agreed upon by the parties. By statute Colorado specifically permits parties to agree on any interest rate, provided it is put in writing. CoLo. Rev. STat. c. 73, art. 1, \& 3 (1953). For compilation of state statutes see Penick, supra note 1, at 428-31; Horack, A Survey of the General Usury Laws, 8 Law \& ConTEMr. Prob. 36 (1941).

3. Rhode Island allows rates of up to $30 \%$ per annum. R.I. Gen. LAws c. $485, \S 2$ (1938). For compilation and tabulation of the various statutes, see Penick, supra note 1 , at 428-31; Horack, supra note 2.

4. Penick, supra note 1 ; Horack, supra note 2.

5. See, e.g., First Nat'l Bank v. Phares, 70 Okla. 255, 174 Pac. 519 (1918) ; C. C. Slaughter Co. v. Eller, 196 S.W. 704 (Tex. Civ. App. 1917); Hafer v. Spaeth, 22 Wash. 2d 378, 156 P.2d 408 (1945); Collins, Evasion and Avoidance of Usury Laws, 8 LAw \& Contemp. Prob. 54 (1941).

6. Bogert, Future of Small Loan Legislation, 12 U. Chi. L. Rev. 1 (1944).

7. Ibid. 
spread enactment of the Uniform Small Loan Law, ${ }^{8}$ covering loans under $\$ 500$, and the recent but rapid development of a pattern of installment loan legislation covering loans up to $\$ 5,000 .^{9}$ These laws permit licensed lenders to charge rates of interest substantially higher than the usury maximums on loans which comply with the detailed provisions of the statutes. They also provide for close administrative investigation and supervision of all aspects of the lender's business. These statutes have been successful in protecting consumer borrowers and have facilitated the enormous growth of consumer credit. $^{10}$ It appears likely that other states will follow the lead of Indiana and Missouri in extending the scope of these statutes and in integrating them into a comprehensive consumer credit code which will cover all forms of installment credit under $\$ 5,000.11$ As a result of these developments, the scope of general usury statutes has been increasingly restricted to the area of commercial lending.

For loans outside the scope of consumer loan legislation, the protection which usury statutes are intended to afford has been virtually eliminated by statutory exemptions and the ease of evasion. Most important of the statutory exemptions is the one granted by fifteen states, including nearly all the large commercial and industrial states, to all loans made to corporations. ${ }^{12}$ In many states there is no limitation on the interest rate which may be charged on

8. Effective laws, based on the Uniform Small Loan Law, have been enacted in all but a dozen states. Kramer, Symposium, The Loan Shark Problem Today, 19 Law \& Contearp. Prob. 1 (1954). Several other states have small loan laws which are ineffective either because the rates allowed are too low, see, e.g., Míss. Code Ann. $\$ \$ 5571-91$ (1942), or an insufficient degree of regulation is provided for, see, e.g., Wro. Coגr. STat. ANw. $\S 39-1111$ - 39-1112 (1945).

9. Thus the Morris Plan or Industrial Loan Banks, originally devised as a means of evading the usury law by the sale of so-called "investment certificates" to every borrower, have received statutory sanction in 29 states and have been put under some degree of regulation. Sixteen states have some regulation of sales financing and most of the states require licensing for sales finance companies. A few of these states sct maximum permissible finance charges. And 20 states now have laws authorizing banks to make installment loans at interest rates above the usury maxirnums. Sel, generally, Hubachek, Progress and Problems in Regulation of Consumer Credit, 19 L/aw \& Contemp. Prob. 4 (1954); Hubachek, The Drift toward a Consumer Credit Code, 16 U. CHI. L. REv. 609 (1949).

10. See articles cited note 9 supra.

11. See Ind. Ann. STAT. $\$$ 19-2201 - 19-2206, 18-3001 - 18-3125, 58-901 - $58-934$ (Burns 1950); Mo. Ans. Star. $\$ \$ 367.100-367.200$, $408.100-408.220$ (Vernon 1952).

12. Del. Code Ans. tit. 6, \$2306 (1953); Ill-Ann. Srat. c. 32, \$\$ 4-6 (1954); Ind. AnN. Stat. § 19-2001 (Burns 1950); Kan. Gen. Stat. \& 17-4103 (1949); Mid. ANw. Code Gen. Laws art. 23, \$121 (1952) ; Mich. Stat. Ann. \$21.78 (1937) ; Minn. Stat. Ann. $\S 334.021$ (West Supp. 1954); Mo. Ann. Stat. $\$ 408.060$ (Vernon 1952); N.J. Stat. Ann. § $31: 1-6$ (1940); N.M. Stat. Ann. § 51-2-34 (1954) ; N.Y. Gen. Bus. Law § 374; Pa. Stat. Ann. tit. 15, \$2852-313 (1938); VA. Code $\$ 6-351$ (1950); W. VA. Code AnN. $\$ 4632$ (1949); WIS. STAT. $\$ 115.06$ (1953).

The courts will generally refuse to pierce the corporate veil even where the debtor incorporated solely for the purpose of obtaining the loan. E.g., Jenkins v. Moyse, 254 N.Y. 319, 172 N.E. 521 (1930) ; Rabinowich v. Eliasberg, 159 Md. 655, 152 Atl. 437 (1930); 
corporate bonds, ${ }^{13}$ and a few states exempt loans over $\$ 5,000$ secured by commercial paper. ${ }^{14}$ Where no exemptions are available, the use of tie-in sales, sales with an option to repurchase, ${ }^{15}$ and excessive "service" charges, such as costs of credit investigations, ${ }^{16}$ are common methods of evasion made possible by the restrictive definitions of loan and interest.

Despite their general ineffectiveness the statutes do have the undesirable effect of restricting the flow of commercial credit and creating a constant, if petty, annoyance to the business community. The maximum rates are too low to allow profitable lending in high-risk situations. Although in most instances the usury statutes can be evaded, the added risk of incurring usury penalties raises the cost of the loan to the borrower. ${ }^{17}$ Moreover, the reluctance of the leading credit institutions to undertake both types of risk considerably limits the available sources of such credit. The dilemma which thus confronts the small businessman in need of a high-risk loan is either to shop for credit with the protection of the usury laws and find none available, or to avoid the usury statutes through incorporation and subject himself to the likelihood of a usurious rate. Finally, the technicalities of these statutes can serve as traps for the unwary though honest lender. ${ }^{18}$

Two alternatives for reform present themselves. The first is to repeal the general usury statutes and allow complete freedom of contract in loan transactions outside the scope of consumer loan legislation. The second is to re-

Silberman v. Cades, 107 N.J. Eq. 574, 153 Atl. 473 (Ct. Err. \& App. 1931). See Note, Usury, Inc.-Incorporation to Avoid Usury Lazws, 7 Mramr L.Q. 375 (1953).

Last year a Queens County grand jury began an investigation of the use of the corporate exemption to evade usury laws. It was alleged that 8,000 people had obtained loans at interest rates of $45 \%$ to $60 \%$, secured by second mortgages on their homes, from so-called "funding corporations" which incorporated the borrower, usually without the latter ever realizing what had been done. N.Y. Times, Feb. 10, 1955, p. 1, col. 2.

13. See, e.g., ORE. Rev. Stat. \$ \$2.120(4) (1953); N.C. Gen. Stat. \$ 24-2 (1952).

14. See, e.g., Pa. Stat. Ann. tit. 41, § 1 (1954); N.Y. Gen. Bưs. Law $\$ 379$.

15. See 6 Corbin, Contracts $\$ 1501$ (1951). Although the courts repeatedly state that they will look through form to substance in determining whether there has been a loan in fact, this has been more "rhetorical calisthenics than practical application." Comment, 6 ARK. L. Rev. 26, 28 (1951).

16. See 6 Corbin, Contracts $\S 1502$ (1951).

17. See 6 id. $\$ 1499$.

18. Such questions as whether or not the maximum rate can be discounted in advance without violating the usury laws are answered differently by the various state's and may easily trap a careless lender.

The classic example of a legitimate commercial lender suffering the harsh penalties of the usury law through a misunderstanding of its technicalities is New York Dry Dock Bank v. American Life Ins. and Trust Co., 3 N.Y. 344 (1849). The Dry Dock Bank, at a time when its credit was impaired, negotiated a loan with a certain Englishman in London for nearly $\$ 200,000$. Interest of $6 \%$ per annum was agreed upon and a bonus was given which raised the actual rate to slightly over $11 \%$ per annum. The Dry Dock Bank subsequently refused to repay the loan on the grounds that it was usurious. The New York Court of Appeals upheld this contention and the lender lost the entire principal and interest. This case led to the exemption of corporations from the usury laws in New York and several other states. RYan, op. cit. supra note 1, at 58. 
place the present fixed-rate test of usury with a standard enabling courts to declare usurious those loans that are found to be harsh and unconscionable.

Repeal would leave the borrower without effective protection from usurious loan contracts. There is still need to retain some protection for borrowers in loan transactions outside the scope of consumer loan legislation. A high degree of bargaining inequality exists in many large personal loans, and in loans to ailing and high-risk enterprises. Generally forced to obtain their loans from a limited group of lenders, and often in a position of borrow or perish, such borrowers are easy prey for the unscrupulous lender. It is true that some courts when faced with unconscionable contracts have given relief to the victimized party by tortured readings of the contract terms ${ }^{19}$ and findings of "constructive fraud," lack of mutuality, and ambiguity. ${ }^{20}$ Such relief is sporadic, however, and often establishes embarrassing precedents. It is also conceivable that usury laws could be replaced gradually by legislation covering specific types of loans as the need for protection arises. However, it is difficult to see how any meaningful classification is possible, and even if it were, this approach would resurrect the same troublesome technicalities of application which plague lenders under present statutes.

Adoption of a statute implementing the doctrine of unconscionability would eliminate the restrictive effects of existing usury laws yet provide adequate protection for borrowers not covered by consumer loan legislation. Such a law should provide that: 1) any interest rate may be agreed to by the paries, but courts may declare any loan transaction usurious where the interest rate is excessive and the loan, taken as a whole, is harsh and unconscionable; 2) if a loan is usurious, the court may order forfeiture of any amount up to perhaps double the interest charged; and 3) if the court finds the borrower's defense groundless and the litigation vexatious it may award, in addition to costs, a reasonable attorney's fee. This statute would give the courts a broad power of review, unhampered by the present restrictive definitions of loan and interest and the numerous statutory exemptions. By providing a flexible standard of usury, a discretionary penalty for dealing with usurious lenders, and a safeguard against vexatious or dilatory litigation by borrowers, such a statute would go far towards removing the cobwebs from a neglected corner of commercial law.

This reform would allow freedom of contract in loan transactions subject only to a standard of good faith and fair dealing. American law has been slowly drifting toward such a limitation on all contract dealings. ${ }^{21}$ And the Uniform Commerical Code codifies this development for sales contracts by providing that a court may set aside any term of a sales contract or the

19. E.g., New Prague Flouring Mill Co. v. Spears, 194 Iowa 417, 189 N.W. $\$ 15$ (1922) ; Bekkevold v. Potts, 173 Minn. 87, 216 N.W. 790 (1927).

20. E.g., Weil v. Chicago Pneumatic Tool Co., 138 Ark. 534, 212 S.W. 313 (1919) (lack of mutuality) ; Hardy v. General Motors Acceptance Corp., 38 Ga. App. 463, 144 S.E. 327 (1928) (vagueness and ambiguity) ; Planters Nat'l Bank v. E. G. Heflin Co, 166 Va. 166, 184 S.E. 216 (1936) (constructive fraud).

21. For discussion and collection of citations see Kessler \& Sharp, Contracts 1-9 (1953). 
entire contract if it finds the contract "harsh and unconscionable."22 Though the section is apparently directed primarily at fine print clauses in order and acceptance forms, the language of the section is general and is not limited in any way to that specific problem. 23 -

A harsh and unconscionable standard has been successfully applied to loan contracts by the English courts for half a century. The English Moneylenders Act of 1900 provides that the courts may reopen any loan made by a professional moneylender and reduce the interest rate to what it considers a reasonable rate if, in view of all the circumstances, the court finds the interest and all other charges "excessive" and the terms of the loan "harsh and unconscionable." 24 The English experience indicates that such a standard is a workable one which need not create undesirable uncertainty in loan transactions.

Recognizing the difficulty of determining whether a given interest rate is excessive, the English courts have refused, except in a few extreme cases, ${ }^{25}$ to find any loan harsh and unconscionable on the basis of a high rate of interest, absent extrinsic evidence of bargaining inequality or trickery and sharp dealing. ${ }^{20}$ Thus in the great majority of commercial loan situations, where neither party has a great advantage in bargaining power, the courts will not interfere with the judgment of the parties. On the other hand, evidence of overreaching or a showing of great bargaining inequality will cause the courts to reopen a loan even where the interest rate is not extraordinarily high. ${ }^{27}$

In determining whether bargaining inequality existed or whether sharp dealing occurred, the courts consider the entire transaction or series of transactions between the parties. ${ }^{28}$ The age, sex and business experience of the parties is considered. ${ }^{20}$ Usually a decisive factor is extreme need of the borrower known to the lender. Any fraud on the part of the lender and, short of fraud, any attempt to conceal the true rate of interest by confusing and misleading methods of computing interest, particularly upon refinancing, is relevant. In short, any action on the part of the lender which though not fraudulent does not constitute fair dealing would, in conjunction with an ap-

22. Uniforar Commerctal Cone $\$ 2-302$.

23. See Comment, 18 U. ChI. L. Rev. 146 (1950).

24. Moneylenders Act, 1900,63 \& 64 VIcr., c. 51. The Act was amended in 1927 to provide for licensing of moneylenders and to require that the borrower be given a written note or memorandum which clearly expresses the interest rate in a per cent per annum and includes all terms of the loan. The amendments further provided that if the interest rate were $48 \%$ per annum or more the lender had the burden of proving that the loan was not harsh and unconscionable. Moneylenders Act, 1927, 17 \& 18 GEo. 5, c. 21.

25. E.g., Fortescue v. Bradshaw, 27 T.L.R. 251 (K.B. 1911) (minimum of $220 \%$ per annum, maximum of $1003 \%$ upon default); Samuel v. Newbold, [1906] A.C. 461 (104\% per annum minimum, $418 \%$ on default).

26. E.g., Reading Trust, Itd. v. Spero, [1930] 1 K.B. 492; Carringtons, Ltd. v. Smith, [1906] 1 K.B. 79.

27. Carringtons, Ltd. v. Smith, supra note 26, at 91 (dictum) ; Blair v. Buckworth, 24 T.L.R. 474 (C.A. 1SOS).

28. B. S. Lyle, Ltd. v. Pearson, [1941] 2 K.B. 391.

29. Sce, e.g., Gerde v. Kerman, 41 T.L.R. 597 (Ch. 1925) ; Stirling v. Musgrave, 29 T.L.R. 333 (K.B. 1912) ; King v. Barnett, 25 T.L.R. 52 (K.B. 1908). 
parently unreasonable interest rate, tend to convince a court that in the circumstances the rate is excessive and the loan harsh and unconscionable. ${ }^{30}$

When a loan is found usurious, the court should have discretion to impose a penalty commensurate with the flagrancy of the lender's conduct. However, the forfeiture should not exceed approximately double the interest charged. If there is no penalty, the borrower merely remitting all in excess of reasonable interest, there is no deterrent effect. The lender has everything to gain and nothing to lose by charging an excessive rate. On the other hand, a fixed severe penalty would deter most courts from declaring any loans usurious. $^{31}$ The courts should have wide discretion in penalizing the usurious lender in view of the difficulty of precise definition and application of a harsh and unconscionable standard,

The enactment of a harsh and unconscionable test for usurious interest rates might encourage a borrower to threaten litigation in order to force a compromise of a fair though expensive obligation. If the lender resisted this threat, allegations of usury would in most cases warrant a trial of the issue with attendant delay and expense. But this has not been a serious problem in England. It seems probable that the discretion of English courts to include attorney's fees in assessing costs has been the major factor in preventing such an abuse. ${ }^{32}$ This weapon should be made available to courts in administering the suggested statute, and there is American precedent for such a provision. The insurance laws of several states allow courts to award attorney's fees to a claimant vexatiously forced to trial by the insurer. ${ }^{33}$ Such a provision might best be implemented by requiring a bond for all costs of trial.

The basic question is whether, in view of the expansion of consumer loan legislation, sufficient need for protection of other borrowers exists to warrant legislation which to some extent at least may cause uncertainty and encourage "strike" suits. It is submitted that a statute such as the one proposed would, in conjunction with comprehensive consumer loan legislation, give full protection to borrowers without undue interference with a free and flexible flow of credit. However, individual state legislatures, sensitive to the political overtones of debtors' problems, are not likely to repeal or modify the present statutes. The best hope for reform in the foreseeable future is the promulgation by the National Conference of Commissioners on Uniform States Laws of a uniform law incorporating the suggested provisions.

30. E.g., Lewis v. Mills, 30 T.L.R. 438 (K.B. 1914) (playing upon fears of the borrower); Stirling v. Rose, 30 T.L.R. 67 (K.B. 1913) (default clause not explained or understood by the borrower); Bonnard v. Dott, 21 T.L.R. 491 (Ch. 1905) (helplessness or folly of the borrower known to the lender).

31. The harsh forfeiture provisions of all early usury laws and many of the modern statutes led to judicial evisceration of these laws by restrictive definition of the terms "Ioan" and "interest." See Seeman v. Philadelphia Warehouse Co., 274 U.S. 403 (1927) ; Yeager v. Ainsworth, 202 Miss. 747, 32 So. 2 d 548 (1947); Note, 4 S.C.L.Q. 290 (1951). See also authorities cited note 5 supra.

32. Cf. Goodhart, Costs, 38 YALE L.J. 849 (1929).

33. See Vance, Insurance $\$ 5$ (3d ed. 1951). 